Daniel, J.C. \& B. Bhushan (1985). The golden gecko of Tirumalai Hills. Hornbill (3): $1718+1$ pl.

Daniel, J.C., B. Bhushan \& A.G. Sekar (1986). Rediscovery of the golden gecko Calodactylodes aureus (Beddome) in the Eastern Ghats of Andhra Pradesh. Journal of the Bombay Natural History Society 83: 15-16, $1 \mathrm{pl}$.

Deraniyagala, P.E.P. (1953b). A Coloured Atlas of Some Vertebrates from Ceylon. Vol. 2, Tetrapod Reptilia. Ceylon Government Press, Colombo, $11+35$ pls., $101 \mathrm{pp}$.

Dutta, S.K., B. Mohanty \& P.P. Mohapatra (2005). Niyamgiri Unravelled. Sanctuary Asia Magazine. October: 56-59.

Murthy, T.S.N. (1990). A field book of the lizards of India. Records of Zoological Survey of India. Occasional Paper 115: 1-122.

Satyamurti, S.T. (1962). Guide to the Lizards, Crocodiles, Turtles and Tortoises Exhibited in the Reptile Gallery. Madras Government Museum, Government of Madras, Madras, 45pp.

Shukla, G.P. (2006). Forests are the most affected. Perspectives on Polavaram - A major irrigation project on Godavari. Academic Foundation, New Delhi, pp.142-149.

\section{SOME NOTES ON THREE SPECIES OF BATS OF JAHANGIRNAGAR UNIVERSITY, BANGLADESH}

\section{M.A. Aziz ${ }^{1}$, A.H.M. Ali Reza ${ }^{2}$, M.K. Hasan ${ }^{3}$, P.K. Tonchangya $^{3}$, A. Sarker ${ }^{3}$, K.M. Atiquzzaman ${ }^{3}$, S. Dutta $^{3}$, Makayching ${ }^{3}$ and K.M.Z. Rahman ${ }^{3}$}

${ }^{1}$ Lecturer, Department of Zoology, Jahangirnagar University, Savar, Dhaka 1342, Bangladesh (Corresponding author)

2 Present address: Department of Range, Wildlife and Fisheries Management, Texas Tech University, Box 42125, Lubbock, TX 79409, USA

${ }^{3}$ Department of Zoology, Jahangirnagar University, Savar, Dhaka 1342, Bangladesh

Email: ${ }^{1}$ wildsamaa@yahoo.com; ${ }^{2}$ ali.reza@ttu.edu

The chiropteran fauna of Bangladesh could exceed the number of species reported until now. Siddiqui (1961) and Ahmed \& Hussain (1982) might have provided the first lists of bats of Bangladesh. Sarker \& Sarker (1988, 2005) reported 17 species and later 29 bats from the country. Bates \& Harrison (1997) reported 16 species of bats from Bangladesh while Khan (2001) provided a detailed account on 31 species of bats. Srinivasulu \& Srinivasulu (2005) after reviewing the previous works mentioned as many as 38 species of bats to be occurring in Bangladesh and speculate that the chiropteran diversity could be more than what is presently known.

In the present project we studied the diversity and morphometry of bats in different habitat types and vegetation cover of Jahangirnagar University.

\section{Study Area}

Jahangirnagar University (JU) $\left(30^{\circ} 16^{\prime} \mathrm{N}-90^{\circ} 26^{\prime} \mathrm{E}\right)$, an area of about $280 \mathrm{ha}$, is situated at the central region of Bangladesh, about $32 \mathrm{~km}$ north of Dhaka city. The undulating land of the
Smith, M.A. (1935). Fauna of British India including Ceylon and Burma. Reptilia and Amphibia. Vol. II, Sauria. Today and Tomorrow's Printers \& Publishers, New Delhi, India.

WWF (2007). Conservation Science, Global 200 Ecoregions. Website: <www. worldwildlife.org/science/ecoregions/g200.cfm> (accessed on 20 February 2007).

\section{ACKNOWLedgements}

The authors wish to acknowledge the constant support and encouragement received from Mr. Anil Kumar, V. Epur, Chairman of WWF-AP State Committee. We are also thankful to Mr. Ashok Kumar, IAS (Retd.), Hyderabad; Dr. A.M. Bauer, Herpetologist, Villanova University, Canada and Mr. P.P. Mohapatra, Herpetologist and Research Scholar, Orissa for providing reference articles and other information. Lastly, we would like to thank Mr. P.S.M. Srinivas, Sales Officer, WWFAPSO, Hyderabad for exploring new places and opening a new vista for biodiversity studies and to Mr. Vikram Aditya, Research Fellow, WWF-APSO, Hyderabad for help in putting the paper together.

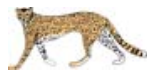

study area has many low lying areas which in monsoon accumulate water and become marshy, but dry up in winter and are used for cultivation (Sultana, 2002). There are 11 permanent lakes in the study area which harbour a huge number of migratory birds during winter season (SeptemberMarch). JU with its diverse ecological habitats such as open grasslands, scrub jungles, cultivated rice fields, small woodlands, permanent and temporary freshwater bodies provides habitats for various kinds of mammals, birds, reptiles, amphibians, fishes and innumerable insects. A total of 233 species of plants belonging to 168 genera under 62 families are reported from the campus (Hossain et al., 1995). The dominating plant species in the campus are Mahua (Madhuca latifolia), Chapalish (Artocarpus chaplasha), Debdaro (Polyalthia longifolia), Amloki (Phyllanthus embelica), Bot (Ficus bengalensis), Jam (Syzygium cumini), Kadam (Anthocephalus chinensis), Kathal (Artocarpus heterophyllus), Mahagoni (Swietenia mahagoni), Tal (Borassus flabellifer), Raintree (Samania saman), Krishnachura (Delonix regia), Am (Mangifera indica) etc. The climatic condition of JU campus is similar to Dhaka city and enjoys hot, humid and rainy summer and cool winter. The highest temperature recorded during April $\left(32.7^{\circ} \mathrm{C}\right)$ and the lowest during January $\left(14.1^{\circ} \mathrm{C}\right)$ with mean rainfall $100.89 \mathrm{~mm}$.

Methods and Materials: The study was conducted from March to August 2005. The phenological cycles of most of the dominating fruit yielding plants in the study area as well as the paddy season coincided with the study period, which ensured the maximum catch of the bat specimens. Mist nets were used for capturing bats in different habitat types and vegetation cover including light post surroundings, old buildings areas and gardens, following Jones et al. (1996). Mist nets were deployed between 1730-1930hr; bats were collected from the net as soon as they were trapped, measured, weighed and photographed, and released as soon as possible from where they were collected. A total of 46 mist net nights were spent

Manuscript 1487; (C) ZOO; Date of publication 21 May 2007 Received 28 December 2005; Revised received 16 November 2006; Finally accepted 26 February 2007 
Table 2. External measurements of the recorded species

\begin{tabular}{|c|c|c|c|c|}
\hline Species & Measurements & Range (cm) & Mean $(\mathrm{cm})$ & SD \\
\hline Pteropus giganteus $(\mathrm{N}=21)$ & $\begin{array}{l}\text { Head-body length } \\
\text { Length of forearm } \\
\text { Length of hind feet } \\
\text { Length of tibia } \\
\text { Ear length } \\
1 \mathrm{ph} 3 \mathrm{mt} \\
2 \mathrm{ph} 3 \mathrm{mt} \\
3 \mathrm{mt} \\
\text { Weight (in g) }\end{array}$ & $\begin{array}{l}21.00-34.50 \\
14.50-17.20 \\
3.40-7.70 \\
6.90-8.70 \\
1.90-3.90 \\
7.00-9.90 \\
9.20-11.90 \\
7.10-11.90 \\
413-578\end{array}$ & $\begin{array}{l}27.34 \\
15.67 \\
6.30 \\
7.61 \\
2.56 \\
8.03 \\
10.55 \\
10.78 \\
449.42\end{array}$ & $\begin{array}{l}3.83 \\
0.82 \\
1.06 \\
0.52 \\
0.54 \\
0.71 \\
0.86 \\
1.18 \\
44.31\end{array}$ \\
\hline Cynopterus sphinx $(\mathrm{N}=12)$ & $\begin{array}{l}\text { Head-body length } \\
\text { Length of forearm } \\
\text { Length of hind feet } \\
\text { Length of tibia } \\
\text { Ear length } \\
\text { Tail length } \\
1 \mathrm{ph} 3 \mathrm{mt} \\
2 \mathrm{ph} 3 \mathrm{mt} \\
3 \mathrm{mt} \\
\text { Weight (in g) }\end{array}$ & $\begin{array}{l}8.50-11.50 \\
5.90-7.50 \\
1.20-2.10 \\
2.10-3.00 \\
1.30-1.90 \\
0.20-1.30 \\
0.20-1.30 \\
3.40-4.30 \\
3.90-5.10 \\
33.00-50.10\end{array}$ & $\begin{array}{l}10.40 \\
6.81 \\
1.73 \\
2.68 \\
1.71 \\
0.78 \\
0.73 \\
3.95 \\
4.48 \\
45.53\end{array}$ & $\begin{array}{l}0.90 \\
0.37 \\
0.27 \\
0.37 \\
0.22 \\
0.37 \\
0.37 \\
0.27 \\
0.33 \\
4.98\end{array}$ \\
\hline Pipistrellus coromandra $(\mathrm{N}=09)$ & $\begin{array}{l}\text { Head-body length } \\
\text { Length of forearm } \\
\text { Length of hind feet } \\
\text { Length of tibia } \\
\text { Ear length } \\
\text { Tail length } \\
1 \mathrm{ph} 3 \mathrm{mt} \\
2 \mathrm{ph} 3 \mathrm{mt} \\
3 \mathrm{mt} \\
\text { Weight (in g) }\end{array}$ & $\begin{array}{l}4.10-4.50 \\
2.50-3.00 \\
0.80-1.00 \\
1.00-1.20 \\
0.70-0.80 \\
2.40-2.50 \\
0.80-1.00 \\
1.30-1.50 \\
02.20-2.80 \\
3.50-4.00\end{array}$ & $\begin{array}{l}4.36 \\
2.78 \\
0.86 \\
1.20 \\
0.70 \\
2.66 \\
0.93 \\
1.43 \\
2.56 \\
2.66\end{array}$ & $\begin{array}{l}0.23 \\
0.34 \\
0.11 \\
0.20 \\
0.05 \\
0.37 \\
0.11 \\
0.11 \\
0.32 \\
0.37\end{array}$ \\
\hline
\end{tabular}

Note: $3 \mathrm{mt}$ : third metacarpal; $1 \mathrm{ph} 3 \mathrm{mt}$ : first phalanx of the third metacarpal; $2 \mathrm{ph} 3 \mathrm{mt}$ : second phalanx of the third metacarpal.

and each session was composed of one to two-and-half hours. Mist nets were placed between $3 \mathrm{~m}$ and $10 \mathrm{~m}$ height from the ground level to capture maximum number of bats that forage in different canopy height. Bates and Harrison (1997) was followed to identify bat species in the field. In addition to the live bats captured by the mist nets, dead bats were also collected from the electric poles located in the study area. These dead bats were also used for morphometric and taxonomic studies.

Results and Discussion: A total of 42 individual bats were studied during the study period. Three species (Table 1) were identified belonging to three genera and two families: Indian Flying Fox (Pteropus giganteus) (21 individuals), Short-nosed Fruit Bat (Cynopterus sphinx) (12 individuals) and Little Indian Bat (Pipistrellus coromandra) (9 individuals).

Pteropus giganteus (Brünnich, 1782) Indian Flying Fox: This large fruit bat, Pteropus giganteus, was recorded to be the most common bat in the study area. They roosted during the day time on trees outside the campus. Large group of bats were observed to enter in the campus from the northern periphery in search of foraging trees. No roosting trees or colonies were found inside the JU campus. Bat groups were recorded to enter inside the campus right after sunset or sometimes even before sunset (1730hrs-1800hrs). P. giganteus showed specific preference for trees from April to August foraging on the flower and fruits of Mahua tree (Madhuca latifolia), and from July through August they moved to Debdaro (Polyalthia longifolia) in addition to the Mahua trees, mostly using the middle and top canopy $(5.5 \mathrm{~m}-15 \mathrm{~m})$ of the foraging trees. In general, $P$. giganteus is a widely distributed and commonly seen bat species throughout the whole country (Khan 2001; Srinivasulu \& Srinivasulu, 2005).

Cynopterus sphinx (Vahl, 1797) Greater Short-nosed Fruit Bat: Cynopterus sphinx is relatively smaller bat and was observed to congregate in small colonies of $3-4$ individuals during the present study. Colonies of up to 25 individuals have been recorded in India by Vasishta \& Badwaik (1994). Diurnal roost sites included the underside of the leaves of Debdaro (Polyalthia longifolia), Kadam (Anthocephalus chinensis), the leaf spaces of Mahogani (Swietenia mahagoni) and the crevices of old buildings of the campus. During the study, this bat was found to be active about half an hour after sunset. Similar observations were made by Khajuria (1979) in India. This species showed specific seasonal food preference in the study area foraging on the flowers and fruits of Mahua (Madhuca latifolia) April through August and on the fruits of Debdaro (Polyalthia longifolia) during July through August. Bats were found in plenty close to these plants during the specific seasons of the year. The middle $(5.5 \mathrm{~m}-7.5 \mathrm{~m})$ and lower $(1.5 \mathrm{~m}-5.5 \mathrm{~m})$ canopy of the trees were used by this bat species.

Pipistrellus coromandra (Gray, 1838) Little Indian Bat: Pipistrellus coromandra is the smallest vespertilionid bat amongst all the recorded species. This bat was recorded from relatively old buildings situated inside the campus. They were observed flying over agricultural fields just after sunset, at elevations 
of $15-18 \mathrm{~m}$ and eating insects in the air. At night, they were also found close to the light posts, flying all around and eating insects. They were observed taking shelter in the old buildings of the campus later at night. Its diurnal roosts found to be the leaf spaces of the shady trees, crevices between old buildings and trees, ceilings and walls of houses. It was found to emerge a few minutes before sunset and even after. The flight is rather slow, fluttering and erratic. It was observed to hunt around big trees and often flew amongst the foliage and surroundings of the light posts of the campus. P. coromandra has a wide distribution in Bangladesh (Khan, 2001; Srinivasulu \& Srinivasulu, 2005).

Conclusion: Although our study area, Jahangirnagar University campus is covered with numerous plants, the numbers and diversity of fruit yielding plant species are not satisfactory. JU campus has problems with exotic plant species (e.g. Acacia monilifornes, Swietenia mahogoni, etc.) that does not offer any support for chiropterans in terms of food. These species should be either replaced or more fruit-yielding native trees should be planted to support local fauna. Development of infrastructure is another problem. Old buildings and trees are being replaced by new ones which are very detrimental for the native environment as well as biodiversity. For the better management of chiropterans in the JU campus, some old buildings and trees should be saved. Naked electric wires crisscrossing the campus should immediately be covered or replaced with plastic coated wires. Naked electric wire is one of the most severe causes for immediate death of a number of Pteropus giganteus due to electrocution every year.

Bats are one of the least studied mammalian groups in the country. Most studies on bats in Bangladesh are mainly based the checklist prepared by the neighbouring countries. There is an obvious dearth of information on bats in the country's wilderness. Extensive surveys are needed throughout the country to understand the current status and distribution of bats. Public awareness is also a crucial component that must be taken into consideration for holistic conservation management plan for the bats of Bangladesh.

\section{REFERENCES}

Ahmed, S.K. and K.Z. Hussain (1982). Bats of Bangladesh. Journal of the Asiatic Society of Bangladesh (Science) 8: 89-99.

Bates, P.J.J. and D.L. Harrison (1997). Bats of the Indian Subcontinent. Harrison Zoological Museum, Kent, England, xvi+258pp.

Hossain, A.B.M.E., S.A. Khan and M.A. Islam (1995). An inventory of plant diversity in relation with ecology and environment of Jahangirnagar University: I. Vegetational composition and their taxonomic identity. Bangladesh Journal of Life Sciences 7(1\&2): 95-103. IUCN Bangladesh (2000). Red Book of Threatened Mammals of Bangladesh. IUCN Bangladesh Country Office, Dhaka, Bangladesh, xii+71pp.

Jones, C., W.J. McShea, M.J. Conroy and T.H. Kunz (1996). Capturing Mammals. In: Measuring and Monitoring Biological Diversity-Standard Methods for Mammals. Wilson, D.E., F.R. Cole, J.D. Nichols, R. Rudran and M.S. Foster (eds.). Smithsonian Institute Press, Washington and London. Khajuria, H. (1979). Taxonomical and ecological studies on bat of Jabalpur District Madhya Pradesh, India. Records of the Zoological Survey of India. Misc. publications. Occasional. Paper 19: 1-59.

Khan, M.A.R. (2001). Status and distribution of bats in Bangladesh with notes on their ecology. Zoos' Print Journal 16(5): 479-483.

Koopman, K.F. (1993). Chiroptera, pp.137-24.1. In: Mammal Species of the World: A Taxonomic and Geographic Reference, $2^{\text {nd }}$ Edition. Wilson, D.E. \& D.M. Reeder (eds.). Smithsonian Institution Press, Washington.

Mickleburgh, S.P., A.M. Hutson \& P.A. Racey (1992). Old World Fruit Bats: An Action Plan for their Conservation. IUCN-The World Conservation Union, Gland, Switzerland, 252pp.

Sarker, S.U. and N.J. Sarker (1988). Wildlife of Bangladesh - A systematic List. Rico Printers, Dhaka, Bangladesh, xix +59pp.

Sarker, S.U. and N.J. Sarker (2005). Bats of Bangladesh with notes on the status, distribution and habitat. Bat Net-CCINSA Nerwsletter 6(1): 19-20.

Siddiqui, M.S. (1961). Checklist of mammals of Pakistan with particular reference to the mammalian collection in the British museum (Natural History), London. Biologia 7(1-2): 93-225.

Srinivasulu, C. \& B. Srinivasulu (2005). A review of chiropteran diversity of Bangladesh. BAT NET-CCINSA Neresletter 6(2): 6-11.

Sultana, S. (2002). Feeding and breeding behaviour of three wetland birds of Jahangirnagar University campus. M.Sc. thesis (unpublished). Jahangirnagar University, Dhaka, Bangladesh.

Vasishta, S.G. and N. Badwaik (1994). An unusual roost choice by the Indian short-nosed fruit bat Cynopterus sphinx gangeticus (Anderson). Journal of the Bombay Natural History Society 91(3): 447.

Walker, S. \& S. Molur (compilers) (2003). Summary of the status of South Asian Chiroptera. Extracted from the CAMP 2002 Report. Zoo Outreach Organization, CBSG, South Asia and WILD, Coimbatore, India, 24pp.

\section{Acknowledgements}

Authors are grateful to the following personnel for their assistance in the field: Azmiri Begum, Abu Saleh Rizvee, Uzzal Kumar Sarder, Sharmin Akhter, and Syed Mahbubur Rahman. 